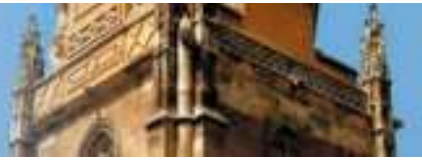

ISSN 1989 - 9572

DOI: 10.47750/jett.2021.12.01.023

\title{
Educating and training labor force Under Covid 19; Impacts to Meet Market Demand in Vietnam during Globalization and Integration Era
}

Nguyen Thi Hang ${ }^{1}$

Duong Thi Tinh ${ }^{2}$

Dinh Tran Ngoc Huy ${ }^{3}$

Pham Thi Hong Nhung ${ }^{4}$

Journal for Educators, Teachers and Trainers, Vol. 12 (1)

https://jett.labosfor.com/

Date of reception: 17 October 2020

Date of revision: 15 January 2021

Date of acceptance: 12 April 2021

Nguyen Thi Hang, Duong Thi Tinh, Dinh Tran Ngoc Huy, Pham Thi Hong Nhung (2021). Educating and training labor force Under Covid 19; Impacts to Meet Market Demand in Vietnam during Globalization and Integration Era. Journal for Educators, Teachers and Trainers, Vol. 12(1). 179 - 184.

${ }^{1} \mathrm{PhD}$, Thai Nguyen University, University of Information and Communications Technology, Vietnam ${ }^{2} \mathrm{PhD}$, Thai Nguyen University of Economics and Business Administration (TUEBA), Vietnam ${ }^{3}$ MBA, Banking University HCMC, Ho Chi Minh city Vietnam - International University of Japan, Japan ${ }^{4}$ Master, Ho Chi Minh College of Econoics, Vietnam 


\title{
Educating and training labor force Under Covid 19; Impacts to Meet Market Demand in Vietnam during Globalization and Integration Era
} Nguyen Thi Hang ${ }^{1}$, Duong Thi Tinh ${ }^{2}$, Dinh Tran Ngoc Huy ${ }^{3}$, Pham Thi Hong Nhung ${ }^{4}$

${ }^{1} \mathrm{PhD}$, Thai Nguyen University, University of Information and Communications Technology, Vietnam

${ }^{2} \mathrm{PhD}$, Thai Nguyen University of Economics and Business Administration (TUEBA), Vietnam

${ }^{3}$ MBA, Banking University HCMC, Ho Chi Minh city Vietnam - International University of Japan, Japan

${ }^{4}$ Master, Ho Chi Minh College of Econoics, Vietnam

Email ID: nthang@ictu.edu.vn, duongthitinh@tueba.edu.vn, dtnhuy2010@gmail.com, hongnnhunghce2911@gmail.com

\begin{abstract}
During integration and globalization era, Vietnam labor market face challenges but also have lots of opportunities. This paper mainly use qualitative analysis with statistics, synthesis and inductive methods, combine with dialectical materialism methods. Research results indicate that because many Vietnam laborers do not have enough work skills and lack of training programs, they meet difficulties on job; hence, human resource management need to deal with issues of improving skills and knowledge for workforce to meet demand under EVFTA and Industry 4.0. There are lots of job opportunities from banking, finance to manufacturing, industries. Last but not least, this study also propose some solutions to deal with challenges in Human resources to meet demand from corporations. For instance, we need to invest more on equipment and infrastructures, as well as quality of trainers for human resources of training schools, so that Vietnam businesses can overcome challenges from EVFTA.
\end{abstract}

Keywords: Education, Labor market, HR management, Vietnam, Challenges

\section{INTRODUCTION}

According to information from VCCI Meeting June/2020, The COVID-19 epidemic has had a great influence on our country's economic and trade situation in recent years. Regarding trade, by the end of May 2020, the total import and export turnover of the country decreased by $2.8 \%$, of which exports decreased by $0.9 \%$, and imports decreased by $4.6 \%$. In April 2020 alone, exports decreased by $27.1 \%$ and imports decreased by $16.4 \%$ from the previous month, and decreased by $13.9 \%$ and $11.4 \%$ over the same period in 2019 , respectively.

According to statistics, Through the information collection channels of the Hanoi Employment Service Center, it shows that the job search demand of workers and the recruitment demand of enterprises in the city tends to increase slightly compared to the previous year 2020 (mostly because 2020 will be affected, so businesses and employees have not been able to prepare thoroughly and promptly) but still quite slow compared to the years that have not been affected by the epidemic situation. . Stemming from many objective and subjective reasons, many enterprises have prepared many contingency plans and plans for the resurgence of the COVID-19 epidemic, so they have not been affected too much on production activities. (source: specials.laodong.vn, access date 19/5/2021).

Hence, businesses in Vietnam need to prepare well for EFVTA integration with many opportunities for labor market and challenges.

This study organized with introduction, literature review, methodology, main results, discussion and conclusion.

\section{LITERATURE REVIEW}

Enchemann and Schwabe (2018) found out Manufacturing companies have to meet a lot of challenges in continuing training for employees. Especially on the way towards industry 4.0 the workforce needs to be able to handle fast changing environments and ever-changing working contexts. Furthermore, they have to be familiar with constantly new technologies (e.g. complex user interfaces, mobile devices) that are introduced during the process of company development. Due to this, working people are facing a lifelong learning process and need to evolve to knowledge workers. To fulfill these requirements new concepts are necessary for human resources development directly at the workplace and therefore adequate artifact designs. In this paper we design a layered architecture for mobile learning at the workplace. This layered approach offers the possibility to educate employees with different.

Beside, Kratchtt (2018) specified that strategies that encourage manufacturers to engage in public and private partnerships, the development of standard skills certifications, and the development of advanced manufacturing 
career pathways are best suited to increase the technical fluency of the workforce while serving to reskill the aging incumbent manufacturing force.

Last but not least, Nguyen Thi Bich Ngoc et al (2020) stated that New-generation FTAs have brought to Vietnam opportunities to sell its agricultural, especially traditional products to the world. The changes could be both negative and positive to the conservation of agricultural products of Vietnam. The authors study four case studies of Gao Ruong Ruoi, Hong Van Cooperative, Sinh Duoc Cooperative and Tam Nguyen Fruit in the context of Europe- Viet Nam Free Trade Agreement and point out that: (i) Incentives for sustainable development for the businesses are not visible; (ii) Agriculture products of Viet Nam face risks due to price competition in domestic market.. The authors also provide policy recommendations to develop sustainable agriculture products in the context of the agreement toward economic and socio-cultural sustainability and inclusiveness for local people.

Deprez (2018) mentioned that political elite of Vietnam has identified trade, export-oriented growth and international economic integration as international policy preferences and has used international trade integration as a strategic instrument to maximise these national priorities within the regional and international trade system. Therefore, Vietnam has a very strategic view on international trade integration and uses it as an instrument to ensure its national interest and security through increased economic power. Through careful selection of trade agreements, Vietnam aims to position itself in a strategically advantageous position vis-à-vis other economies of the AEC, to ensure continued economic growth through preferential access to key markets and to push through some of the more difficult and sensitive domestic economic reforms, using its commitments under external trade agreements as a lock-in mechanism.

Practices in Vietnam show that The employees are hardly trained and put to work immediately, their skill level is very limited. This results in low labor productivity and low competitiveness of businesses in particular for the whole economy in general.

In addition, the employees' rights are not guaranteed, they are not adequately protected due to lack of qualifications. Workers also have to bear occupational safety risks due to lack of labor skills, being underpaid, being fired at any time when the business changes technology, ...

\section{METHODOLOGY}

This study mainly uses qualitative methods, statistics, with synthesis, analytical and inductive methods, combined with dialectical materialism analysis.

\section{MAIN RESULTS}

Opportunities: First, The EVFTA Agreement will ensure working conditions for employees. Commitments on labor issues in the EVFTA Agreement as well as the new generation free trade agreements have become a common requirement and trend nowadays, as development partners have higher requirements. in addition to economic development objectives such as labor, environment, climate change, natural resources, etc. Labor commitments are provided for in Article 3 of the Trade and Sustainable Development Chapter of the EVFTA Agreement, issue multilateral labor standards and agreements on trade-related issues. Accordingly, Vietnam and the EU are committed to promoting trade development while helping create sustainable and rich jobs for all, and approving and fulfilling the obligations and regulations of International Labor Organization (ILO) Basic Conventions.

The basic principles and labor rights outlined in the 1998 ILO Declaration include: freedom of association and effective recognition of the right to collective bargaining; eliminating all forms of forced or compulsory labor; abolishing the effectiveness of child labor; and eliminate discrimination in employment and occupation. As such, these commitments will contribute to improving working conditions, reproducing labor power and improving the quality of human resources. Specifically, workers will have the opportunity to improve their legal rights in both minimum income, work and living environment, as well as opportunities to join associations and unions, including looking for new job opportunities. 


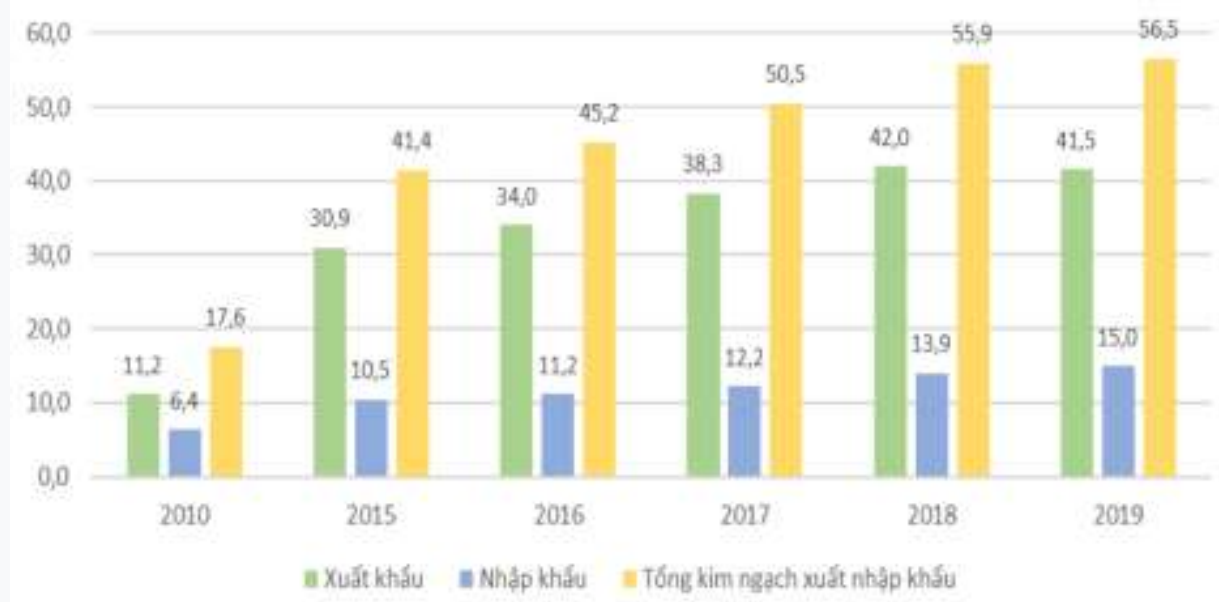

Chart 1: Net import-export between Vietnam -EU 2015-2019

Looking at above chart 1 we recognize that most of years 2015-19 Vietnam exports to EU much higher than import and net values in 2019 reached $56.5 \mathrm{~b}$ USD, compared to $17.6 \mathrm{~b}$ USD in 2015. More opportunities for laborers working in exporting industries.

\section{Challenges}

Table 1: Proportion of workers working in the trained economy by professional and technical qualifications of Vietnam, 2015 - 2019

\begin{tabular}{|l|l|l|l|l|l|}
\hline Contents & $\mathbf{2 0 1 5}$ & $\mathbf{2 0 1 6}$ & $\mathbf{2 0 1 7}$ & $\mathbf{2 0 1 8}$ & $\mathbf{2 0 1 9}$ \\
\hline Total & $\mathbf{2 0 . 4}$ & $\mathbf{2 0 . 9}$ & $\mathbf{2 1 . 6}$ & $\mathbf{2 2 . 0}$ & $\mathbf{2 2 . 8}$ \\
\hline Primary & 3.3 & 3.2 & 3.5 & 3.6 & 3.7 \\
\hline Prof Mid Colleges & 5.4 & 5.3 & 5.3 & 5.2 & 4.7 \\
\hline Colleges & 3.0 & 3.2 & 3.3 & 3.7 & 3.8 \\
\hline University and higher & 8.7 & 9.2 & 9.5 & 9.5 & 10.6 \\
\hline
\end{tabular}

Unit: \% Source: Vietnam Statistical Yearbook 2019

Specifically, the rate of trained workers aged 15 years and over who are working in the economy has gradually increased over the years, but by 2015 the rate of workers with diplomas and certificates only reached $20.4 \%$; in 2019 it will reach $22.8 \%$. Thus, the whole country currently has up to 43.05 million workers (accounting for $77.2 \%$ of the total number of employees) who have not been trained to reach a certain professional and technical level. In addition, the labor structure by training qualifications of our country is still unreasonable, in 2019 the correlation ratio between university and higher level - college - intermediate level - elementary, respectively: 1-0, 35-0.440.34 , this warns of a shortage of practical engineers and high-level technical workers.

Another difficulty is meeting labor standards, including the requirement not to use child labor. In a certain sense, this rule will also cause many seafood businesses to change their labor structure, especially during the booming harvest season or in urgent times of serving too many due orders. That will lead to labor scarcity and the cost of labor can be pushed up, costing businesses a lot more.

Moreover, New technology will still require human workers. Companies that embrace new technology are growing, which leads to more jobs and different kinds of jobs. Hence, laborers need to be trained to meet demand (higher) during Industry 4.0.

\section{DISCUSSION}

According to statistics, Only in the first 6 months of 2020, about 1.4 million people lost their jobs, of which workers lost their jobs due to bankruptcy, dissolution or production reduction of nearly 900 thousand people. people. In the context of continuously increasing unemployed workers, the results of job creation in the first 6 months of the year were very low, estimated at 540,000 employees. According to experts and state management agencies, the labor market is being severely affected by the COVID-19 epidemic.(source: specials.laodong.vn, access date 20/5/2021).

Thus, the Vietnamese labor market is facing the challenge of "low quality of labor" - a barrier for businesses to take advantage of opportunities from EVFTA. One of the main reasons is the low level of training and professional qualifications of Vietnamese workers, reflected in the low rate of trained workers, inadequate training structure, and shortage of laborers with high skills, the gap between vocational education and labor market demand remains large. 
EVFTA is also a comprehensive, high quality, balanced agreement of interests for both Vietnam and the EU, and in accordance with the provisions of the World Trade Organization (WTO). Agreement consists of 17 chapters, 2 protocols and a number of memorandums of understanding with the main contents, which are: Trade in goods (including general provisions and commitments to open markets); rules of origin, customs and trade facilitation; food safety and hygiene measures; technical barriers to trade; trade in services, investment, trade defense; competition, state-owned enterprises (DN); Government procurement, intellectual property; trade and sustainable development, cooperation and capacity building;

\section{CONCLUSION}

Hence, Vietnam corporations need to prepare well before EVFTA.

Vietnam labor workforce also need training programs to improve knowledge and skills before EVFTA.

Universities, Colleges and training centres need to offer suitable courses for laborers.

We also need communication channels to change the awareness of parents, students, workers, businesses about vocational training, in which training and retraining for employees is very important content; focus on on-demand training for both employees and businesses;

Beside, training schools need to invest more on equipment and infrastructures, as well as enhancing effectiveness of educational programs and increase productivity.

Limitation of research: This study can be expanded into more details for training programs for laborers.

Acknowledgement: Thank you very much for editors and friends support to publish this article.

\section{REFERENCES}

1. Deprez, S. (2018). The Strategic Vision behind Vietnam's International Trade Integration, journal of Current Southeast Asian Affairs, 4. https:/ / doi.org/10.1177/186810341803700201

2. Engelmann, A., \& Schwabe, G. (2018). Enabling Workers to Enter Industry 4.0: A Layered

3. Huong, N.M., An, L.T.T., Huy, D.T.N., Thanh, N.T.P., Lan, N.T.P., Huong, C.T.M., \& Nam, M.V. (2021). Teaching methods of history and geography and it influence for students in primary schools, vietnam, Journal for Educators, Teachers and Trainers, 12(1).

4. Le Thi Thanh Huong, Do Thu Huong, Dinh Tran Ngoc Huy, Nguyen Thu Thuy. (2021), Education for students to enhance research skills and meet demand from workplace - case in Vietnam, Elementary Education Online, 20(4): 606-611. Doi: 10.17051/ilkonline.2021.04.66

5. Nguyen Manh Huong (2011), Improving teaching quality of History at high schools with the support of information technology, Doctoral thesis in Education, National Library, H, 2011

6. Ministry of Education and Training (2006), Decision No. 16/2006 / QD-BGDĐT dated 05/05/2006 Promulgating General Education Program, Vietnam.

7. Ministry of Education and Training (2018), General Education Program Master Program, Hanoi, Vietnam.

8. Koen Aesaert, Daniël Van Nijlen, Ruben Vanderlinde, Jo Tondeur, Ines Devlieger, Johan van Braak (2015), The contribution of pupil, classroom and school level characteristics to primary school pupils' ICT competences: A performance-based approach, Computers \& Education, 87, pp. 55-69.

9. Phan Ngoc Lien (2009) (Editor). Teaching Methodology History (Vol.1, 2), Pedagogical University Publishing House, Hanoi, Vietnam.

10. Skjaeveland, Y. (2017). Learning history in early childhood: Teaching methods and children's understanding, Contemporary issues in early childhood, 1.

11. https://doi.org/10.1177/1463949117692262

12. Thuy Dung Thi Vu, Le Thi Thanh Huong, Dinh Tran Ngoc Huy, Le Ngoc Nuong, Ngo Thi Huyen Trang, Nguyen Ngoc Thach. (2021). Human Education and Educational Issues for Society and Economy - Case In Emerging Markets Including Vietnam, Elementary Education Online, 20(2): 216221. Doi: 10.17051/ilkonline.2021.02.27

13. Mobile Learning Architecture, Proceedings of the 51st Hawaii International Conference on System Sciences.

14. Krachtt, N. (2018). The Workforce Implications of Industry 4.0: Manufacturing Workforce Strategies to Enable Enterprise Transformation, Seminar Paper, University of Wisconsin-Platteville

15. Ngô Thắng Lợi (2013). Giáo trình Kinh tế Phát triển. NXB Kinh tế Quốc dân. Hà Nội

16. Nguyễn An Hà (2014). Vietnam labor market in the context of international integration. Wies I Rolnictwo, NR 4 (165).

17. 13.The world bank. https://data.worldbank.org/country/vietnam. (date access 16/03/2020). 
18. 14. Thuy Dung Vu Thi, Tran Nguyet Minh Thu, Dinh Tran Ngoc Huy, Nguyen Thu Thuy. (2021). Effects of western culture and ho chi minh ideology on Vietnam education, Elementary education online, 20(4): 612-616. Doi: 10.17051/ilkonline.2021.04.67

19. 15. Tran Nguyet Minh Thu, Thuy Dung Vu Thi, Nguyen Thu Thuy, Dinh Tran Ngoc Huy. (2021). Confucianism Theories and Its Influence on Vietnam Society, Elementary Education Online, 20(4):1434-1437.

20. 16. Tran Nguyet Minh Thu, Dinh Tran Ngoc Huy, Thuy Dung Vu Thi, Le Ngoc Nuong. (2021). Effects of western and chinese culture and ideology on vietnam society, Elementary Education Online, 20(4): 1438-1441. Doi: 10.17051/ilkonline.2021.04.163

21. 17. Trần Xuân Cầu (2013). Giáo trình Kinh tế nguồn nhân lực. NXB Kinh tế Quốc dân. Hà Nội

22. 18. Ministry of Trade and Industry, World Bank (2016). Kỷ yếu hội thảo "Việt Nam: Nắm bắt cơ hội của các hiệp định Thương mại tự do thế hệ mới". Tổ chức ngày 05/09/2016. Việt Nam. http://documents.worldbank.org/curated/en/123901521747722857/pdf/124458-VIETNAMESEPUBLIC-VietNamSeizingopportunitiesfromnewgenerationFTAsVnese.pdf

23. VCCI (2019).

24. 19.Báo cáo nghiên cứu Tác động của Hiệp định Thương mại tự do Việt Nam - Liên minh Châu Âu (EVFTA) đến quan hệ lao động tại nơi làm việc ở Việt Nam. Hà Nội. http:/ / beavccivietnam.com.vn/upload/attach/2019102915516-BEAVCCI.pdf

25. $w w w$.google.com/url? sa $=t \& r c t=j \& q=\& e s r c=s \& s o u r c e=w e b \& c d=1 \& v e d=2 a h U K E w j U i O C Z 3 Z f o A$ hVHHKYKHfleA9MQFjAAegQIAxAB\&url=http\%3A\%2F\%2Fkwartalnik.irwirpan.waw.pl\%2Fdi r_upload\%2Fphoto\%2F090bc5a87d30b8a0ccb5a88afdaa.pdf\&usg=AOvVaw0wCgWYjWApKSRK Q47POHKx

26. Vietnam Bureau statistics. https://www.gso.gov.vn/Default.aspx?tabid=217. (date access 17/03/2020).

27. http:// tapchicongthuong.vn/bai-viet/thuc-trang-nang-suat-cua-nen-kinh-te-viet-nam-qua-cacnam-gan-day-va-giai-phap-cho-cac-nam-tiep-theo-63818.htm

28. https://trithucvn.net/kinh-te/nang-suat-lao-dong-cua-viet-nam-thap-nhat-trong-khu-vuc-baitoan-kho-giai.html

29. https://www.dinhtranngochuy.com (access date 20/5/2021) 